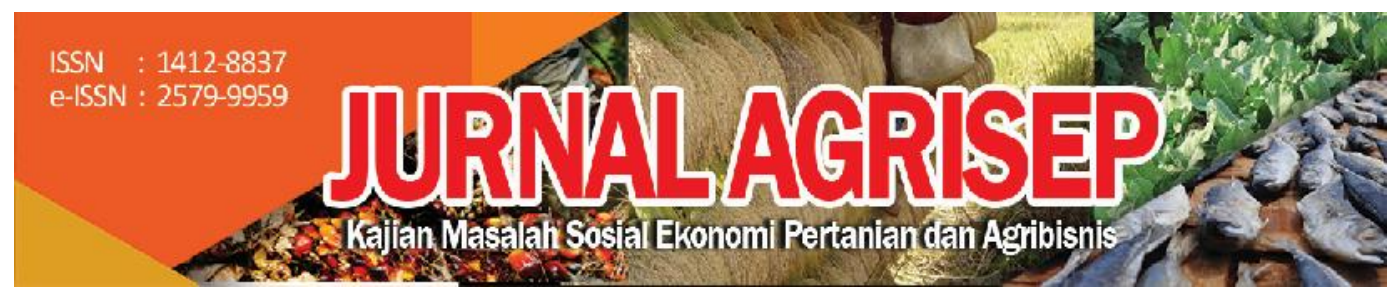

DOI: 10.31186/jagrisep.18.2.249-268

\title{
PROFITABILITAS DAN EVALUASI KINERJA PRODUK AGROINDUSTRI RUMAH TANGGA GULA KELAPA KECAMATAN LAIS KABUPATEN BENGKULU UTARA PROVINSI BENGKULU
}

\author{
Profitability and Performance Evaluation of Coconut Sugar Home \\ Agroindustry Product Lais District North Bengkulu Regency Bengkulu \\ Province
}

\author{
Efa Yulita Fitri; Nusril; Reswita $\square$ \\ Jurusan Sosial Ekonomi Pertanian Fakultas Pertanian Universitas Bengkulu \\ Email : reswita17@yahoo.co.id
}

\begin{abstract}
In the Home Industry of coconut sugar, the cost and profit calculation is still conventional. Profit calculation is needed in order to get the maximum profit of the business. The company's profit is related to cost, sales volume and selling price. One of the analytical tools that can be used is Cost Volume Profit (CVP) analysis. Profitability is a benchmark of the company's performance to generating the net income. The research aim to analyze the income, breakeven point, profitability ability and sensitivity, also analysing consumer perception about attribute level of importance and satisfaction of coconut sugar product in Dusun Hibrida, Pal 30 Village, Lais District, North Bengkulu Regency, Bengkulu Province. From sales of coconut sugar products amounted to Rp.60.183,47 per production. Which the profitability of coconut sugar products is $46 \%$. If product performance exceeds the consumer expectations, they will feel satisfied. Importance Performance Analysis (IPA) is used to maping the relationship between importance and performance of each product attribute. The most important attributes and have good performance related to consumers is coconut sugar hygiene, taste, and food / beverages, coconut sugar color, durability, ease of accessing the product, and coconut sugar solubility, that's attributes need to be maintained.
\end{abstract}

Keywords: Coconut Sugar, Profitability, Product Performance, CVP, IPA 


\begin{abstract}
ABSTRAK
Dalam usaha Home Industry gula kelapa, perhitungan biaya dan laba masih sederhana. Perhitungan laba sangat dibutuhkan agar usaha yang dijalankan dapat memperoleh keuntungan yang maksimal. Laba perusahaan berhubungan dengan biaya, volume penjualan dan harga jual. Salah satu alat analisis yang dapat digunakan adalah analisis Cost Volume Profit (CVP). Profitabilitas merupakan tolak ukur kinerja dan keberhasilan perusahaan dalam menghasilkan laba bersih. Ketika kinerja produk memenuhi atau melebihi harapan konsumen, maka konsumen akan merasa puas. Importance Performance Analysis (IPA) digunakan untuk memetakan hubungan antara tingkat kepentingan dengan kinerja dari masing-masing atribut produk.Tujuan dari penelitian ini adalah untuk menganalisis pendapatan, titik impas, kemampuan laba dan sensitivitas Home Industry pengolahan gula kelapa dan untuk menganalisis persepsi konsumen tentang tingkat kepentingan dan kepuasan terhadap atribut-atribut produk gula kelapa di Dusun Hibrida, Desa Pal 30, Kecamatan Lais, Kabupaten Bengkulu Utara, Provinsi Bengkulu. Hasil penelitian menunjukkan bahwa pendapatan yang diperoleh dari penjualan produk gula kelapa sebesar Rp.60.183,47 per Produksi dengan Profitabilitas produk gula kelapa untuk memperoleh laba sebesar 46\%. Kemudian, Atribut yang menurut konsumen penting dan kinerjanya sudah baik adalah kehigienisan gula kelapa, rasa gula kelapa dan makanan/minuman, warna gula kelapa, daya tahan gula kelapa, kemudahan mendapatkan gula kelapa dan kelarutan gula kelapa, atributatribut tersebut perlu dipertahankan.
\end{abstract}

Kata Kunci: Gula Kelapa, Profitabilitas, Kinerja Produk, CVP, IPA.

\title{
PENDAHULUAN
}

Kecamatan Lais Kabupaten Bengkulu Utara merupakan wilayah sentra perkebunan kelapa di Propinsi Bengkulu dengan jumlah unit usaha gula kelapa sebanyak 118 unit usaha, jika dibandingkan dengan Kabupaten Bengkulu Selatan yang hanya 36 unit usaha gula kelapa (Disperindag, 2016). Luas pertanaman kelapa di Kecamatan Lais seluas 167 Ha. Dipilihnya Kecamatan Lais, tepatnya adalah Dusun Hibrida, didasarkan pada pertimbangan bahwa usaha gula kelapa telah menjadi lapangan usaha bagi sebagian besar rumah tangga penduduk setempat

Banyak konsumen yang mulai tidak menggunakan gula kelapa dikarenakan banyak isu yang beredar tentang rendahnya kualitas gula kelapa. Pada proses produksi ada beberapa pemilik usaha mencampurkan bahan lain seperti deterjen (Radar pat petulai news. com, 2017). Dengan penelitian ini, diharapkan dapat mengurangi bahkan menghilangkan prasangka-prasangka buruk tentang produk gula kelapa khususnya dari Dusun Hibrida, Desa Pal 30, Kecamatan Lais, Kabupaten Bengkulu Utara. Peneliti juga ingin melihat bagaimana pendapatan dan rugi/laba pengusaha gula kelapa dalam 
menjualkan produk mereka. Sehingga harapan untuk masa depan bagi pengusaha gula kelapa adalah terjaminnya kualitas dari produk tersebut.

Dalam usaha Home Industry gula kelapa, perhitungan biaya dan laba masih sederhana. Perhitungan laba sangat dibutuhkan agar usaha yang dijalankan dapat memperoleh keuntungan yang maksimal. Laba perusahaan berhubungan dengan biaya, volume penjualan dan harga jual. Salah satu alat analisis yang dapat digunakan untuk menghubungkan perubahan tiga variabel tersebut dalam satu kesatuan disebut analisis

Tujuan dari penelitian ini adalah Untuk menganalisis pendapatan, titik impas, kemampuan laba dan sensitivitas Home Industry pengolahan gula kelapa dan Untuk menganalisis persepsi konsumen tentang tingkat kepentingan dan kepuasan terhadap atribut-atribut produk gula kelapa di Dusun Hibrida, Desa Pal 30, Kecamatan Lais, Kabupaten Bengkulu Utara, Provinsi Bengkulu. Untuk membandingkan sampai sejauh mana antara kinerja/pelayanan yang dapat dirasakan oleh konsumen dengan tingkat kepuasan yang diinginkan oleh konsumen.

\section{METODE PENELITIAN}

\section{Tempat dan Waktu}

Penelitian ini dilaksanakan Di Dusun Hibrida,Desa Pal 30, Kecamatan Lais, Kabupaten Bengkulu Utara. Provinsi Bengkulu. Pada tanggal 22 Desember 2017. Penentuan lokasi dilakukan sengaja (Purposive) dengan pertimbangan bahwa di Dusun tersebut merupakan sentra produksi gula kelapa.

\section{Pengambilan Responden}

Total responden pada penelitian ini sebanyak 90 responden. Responden pemilik usaha dan konsumen gula kelapa diteliti masing-masing sebanyak 45 responden. Kriteria-kriteria responden pemilik usaha, yaitu jumlah produksi gula kelapa minimal $5 \mathrm{~kg}$ per hari, usaha yang dilakukan lebih dari 5 tahun, pekerjaan pemilik usaha hanya memproduksi gula kelapa yang diambil secara sensus dan kelompok konsumen untuk menganalisis kinerja produk gula kelapa sebanyak 45 responden diambil secara snowball sampling.

\section{Pengumpulan Data}

Data yang dikumpulkan dalam penelitian ini ada dua macam, yaitu data primer dan data sekunder. Data primer diperoleh secara langsung dari responden melalui wawancara dengan menggunakan kuesioner (Daftar Pertanyaan) yang telah disiapkan. Data sekunder adalah data-data pendukung yang didapatkan dari literatur- literatur atau sumber lain yang disajikan dalam bentuk jurnal, karya tulis, laporan penelitian dll. 


\section{Analisa Data}

Metode Analisis data yang akan digunakan adalah Cost Volume Profit (CVP) dan Importance Performance Analysis (IPA).

\section{Cost Volume Profit}

Analisis Cost Volume Profit adalah studi mengenai efek dari perubahan pada biaya dan volume pada profit perusahaan (Reswita, 2010). Bagi perusahaan, penting untuk membuat perencanaan laba karena akan ada beberapa critical factors yang muncul terkait keputusan manajemen, seperti pricing, product mix, dan fasilitas-fasilitas yang lainnya.

\section{Pendapatan}

Laporan rugi/laba dilakukan untuk melihat berapa laba bersih yang dihasilkan pada produksi gula kelapa. Dengan mengetahui laba bersih maka pendapatan dari produksi gula kelapa juga didapatkan. Laba/rugi dapat dihitung sebagai berikut :

Tabel 1. Perhitungan Pendapatan dengan menggunakan metode Laba/Rugi

\begin{tabular}{ll}
\hline Penjualan & Rp. XXX \\
Biaya Variabel & Rp. XXX - \\
Margin Kontribusi & Rp. XXX \\
Biaya Tetap & Rp. XXX - \\
Laba & Rp. XXX \\
\hline
\end{tabular}

Sumber: HB, 2011

\section{Contribution Margin}

Contribution Margin (margin kontribusi) merupakan jumlah yang tersisa untuk menutupi biaya tetap dan mencetak laba usaha (Simamora, 2012). Secara matematis Contribution Margin dapat ditentukan sebagai berikut:

Margin Kontribusi $(\mathrm{Rp} . / \mathrm{kg})=$ Penjualan-Biaya Variabel

Rasio Margin Kontribusi $(\%)=\frac{M \text { argin Kontribusi }}{\text { Penjualan }} \times 100 \%$

\section{Break Event Point}

Titik impas ialah volume penjualan dimana jumlah pendapatan dan jumlah bebannya sama, tidak ada laba maupun rugi bersih (Simamora, 2012). 
Titik Im pas (dalam rupiah penjualan $)=\frac{\text { Biaya Tetap }}{\text { Rasio Marjin Kontribus }}$

Titik Im pas $($ dalam unit penju alan $)=\frac{\text { Biaya Teta } p}{\text { Marjin Kon tribus per unit }}$

\section{Profitabilitas}

Profitabilitas memiliki peran penting didalam perusahaan karena melalui profitabilitas yang tinggi dimiliki perusahaan, maka perusahaan tersebut akan mampu membayar segala kewajiban - kewajiban yang dimiliki oleh perusahaan. (Hanum, 2012). Profitabilitas dapat dinyatakan dengan:

$$
\pi=\text { MOS }- \text { MIR }
$$

\section{Margin of Safety (MOS)}

Menurut Eti verawati (2014), Margin of safety yang besar menunjukan bahwa kondisi perusahaan tidak dalam bahaya, dan sebaliknya jika Margin of Safety kecil mendekati nol persen menunjukan bahwa perusahaan dalam kondisi bahaya yaitu akan mengalami titik impas. Rumus perhitungan Margin of safety adalah:

$$
\text { MOS }=\frac{\text { Penjual Aktual }- \text { BEP }}{\text { Penjualan Aktual }} \times 100 \%
$$

\section{Margin Income Ratio (MIR)}

Margin Income Ratio (MIR) merupakan bagian hasil penjualan yang tersedia untuk menutup biaya tetap dan laba. MIR dapat memberikan informasi tentang berapa bagian dari penjualan yang tersedia untuk menutupi biaya tetap dan memperoleh laba. MIR dapat diperoleh dari hasil bagi laba kontribusi dengan pendapatan penjualan. Laba kontribusi merupakan kelebihan pendapatan penjualan di atas biaya variabel (Mulyadi 2001). Rumus perhitungan Margin Income Ratio adalah:

$$
\text { MIR }=\frac{\text { Penjual Aktual }- \text { Biaya Variabel }}{\text { Penjualan Aktual }} \times 100 \%
$$

\section{Degree of Operating Leverage (DOL)}

Degree of Operating Leverage (DOL) digunakan untuk mengetahui sejauh mana laba perusahaan dapat berubah jika terdapat peningkatan ataupun penurunan penjualan pada usaha. Rumus Degree of Operating Leverage (DOL) sebagai berikut: 


$$
D O L=\frac{\text { Margin Kontribusi }}{\text { Labab Bersih }}
$$

\section{Importance Performance Analysis (IPA)}

Menurut Yola dan Budianto (2016), Importance Performance Analysis (IPA), merupakan alatbantu dalam menganalisis atau yangdigunakan untuk membandingkan sampaisejauh mana antara kinerja atribut produk dan penting tidaknya atribut-atribut produk yang dapat dirasakan oleh pengguna jasa dibandingkan terhadap tingkat kepuasan yang diinginkan. Faktor-faktor yang mempengaruhi sebagai berikut:

Tabel 2.Atribut Gula Kelapa

\begin{tabular}{|c|c|c|c|}
\hline 1. & Harga beli gula kelapa & 9. & $\begin{array}{l}\text { Kemudahan mendapatkan gula } \\
\text { kelapa pada saat ingin membeli } \\
\text { gula kelapa }\end{array}$ \\
\hline 2. & Kehigienisan gula kelapa & 10. & Kelarutan gula kelapa \\
\hline 3. & $\begin{array}{l}\text { Rasa gula kelapa dan makanan/ } \\
\text { minuman menggunakan gula } \\
\text { kelapa }\end{array}$ & 11. & Kemasan yang menarik \\
\hline 4. & Warna gula kelapa & 12. & Label Komposisi Bahan \\
\hline 5. & Ukuran gula kelapa & 13. & Label Halal \\
\hline 6. & Bentuk gula kelapa & 14. & Informasi Perizinan \\
\hline 7. & Tekstur gula kelapa & 15. & $\begin{array}{l}\text { Papan Nama Tempat } \\
\text { Pengolahan Gula Kelapa }\end{array}$ \\
\hline 8. & $\begin{array}{l}\text { Daya tahan gula kelapa untuk } \\
\text { disimpan }\end{array}$ & 16. & $\begin{array}{l}\text { Promosi dari mulut ke mulut } \\
\text { (Word of Mouth) }\end{array}$ \\
\hline
\end{tabular}

Menghitung Rata- rata untuk Setiap Atribut yang Dipersepsikan oleh Konsumen

$$
\bar{X}=\frac{\sum x_{i}}{n} \operatorname{dan} \bar{Y}=\frac{\sum y_{i}}{n}
$$

dimana: $\bar{X}$ adalah Skor rata-rata tingkat kinerja produk; $\bar{Y}$ adalah Skor rata-rata tingkat kepentingan terhadap produk; $\mathrm{Xi}$ adalah Skor atribut kinerja; Yi adalah Skor atribut kepentingan; dan $\mathrm{n}$ adalah Jumlah responden 


\section{HASIL DAN PEMBAHASAN}

\section{Karakteristik Responden}

Karakteristik responden adalah gambaran kondisi umum responden yang diamati. Responden yang diteliti adalah pemilik usaha Home Industry gula kelapa di Dusun Hibrida Desa Pal 30 Kecamatan Lais Kabupaten Bengkulu Utara dan konsumen gula kelapa yang terdiri dari Ibu rumah tangga, pedagang dan pengumpul. Karakteristik yang dikaji meliputi: umur, tingkat pendidikan, pengalaman usaha, tanggungan keluarga dan pekerjaan Konsumen.

Umur merupakan faktor penting dalam menjalankan usaha Home Industry gula kelapa. Umur mempengaruhi produktivitas seseorang dalam berusaha. Saat umur masih muda pemilik usaha relatif mempunyai kemampuan fisik yang kuat untuk melakukan kegiatan usahanya. Sebaliknya untuk seseorang yang telah lanjut usia kemampuan fisik orang tersebut sudah berkurang dalam melakukan kegiatan usahanya.

Pendidikan merupakan salah satu faktor penunjang dalam cara berpikir, bersikap dan bertindak sehingga usaha yang dijalankan akan lebih baik. Pemilik usaha dankonsumengula kelapa banyak berada pada tingkat pendidikan SD. Hal ini dikarenakan pemilik usaha tidak memilik uang untuk melanjutkan pendidikan sehingga lebih memilih untuk menjalankan usaha dan membantu orang tua mereka.

Jumlah anggota keluarga sangat mempengaruhi didalam memenuhi kebutuhan sehari-hari semakin banyak anggota keluarga maka semakin banyak pula kebutuhan yang diperlukan. Oleh karena itu, Jumlah anggota keluarga dapat menentukan jumlah konsumsi dan kebutuhan keuangan rumah tangga tersebut.Jumah tanggungan konsumen gula kelapa terbilang sedikit hal ini dikarenakan banyak anak-anak dari pemilik usaha yang telah menikah sehingga telah keluar dari kartu keluarga (KK) dan telah pindah dari rumah. Semakin sedikit jumlah tanggungan keluarga maka semakin sedikit pula konsumsi gula kelapa tersebut, sebaliknya semakin banyak jumlah tanggungan keluarga konsumsi gula kelapa juga semakin banyak.

Pengalaman usaha biasanya dapat menjadi tolak ukur dalam pengambilan keputusan yang akan dilakukan untuk produksi berikutnya. Pengalaman usaha akan menjadikan pemilik Home Industryakan semakin terampil dibandingkan yang memiliki pengalaman usaha yang lebih sedikit.Pengalaman usaha pemilik usaha Home Industry gula kelapa mempunyai kategori sedang dengan pengalaman usaha sebesar 9,3-13,6. Rata-rata pengalaman usaha sebesar 11,4 tahun. Hal ini berarti, usaha yang dilakukan rata-rata responden telah berlangsung lama dikarenakan hanya usaha inilah yang dijadikan sumber keuangan pemilik usaha gula kelapa.

Pekerjaan dapat diartikan sebagai keterampilan yang dihargai dengan uang. Dengan bekerja maka seseorang akan mendapatkan uang untuk 
keberlangsungan hidupnya. Pekerjaan akan mempengaruhi seberapa banyak konsumsi yang dibeli dan dibutuhkan.Jenis pekerjaan dapat mempengaruhi pembelian konsumen terhadap produk gula kelapa.Pedagang pengumpul merupakan pembeli gula kelapa terbanyak dikarenakan pedagang pengumpul juga menjualkan gula kelapa dengan skala besar sehingga pembelian gula kelapa juga besar sebaliknya ibu rumah tangga dan PNS merupakan konsumen pembeli gula kelapa yang hanya membeli gula kelapa untuk kebutuhan masak ataupun hanya untuk membuat makanan tertentu saja.

\section{Proses Produksi Gula Kelapa}

Proses produksi gula kelapa dimulai dari pengambilan bahan baku yaitu nira kelapa. Proses penyadapan nira kelapa ini akan dilakukan setiap pagi dengan lama waktu dua sampai tiga jam lamanya tergantung dengan banyaknya pohon kelapa yang akan disadap.

Pada proses pembuatan gula kelapa bahan-bahan yang digunakan dalam pembuatan gula kelapa ini adalah nira kelapa sebagai bahan baku dan kelapa parut sebagai bahan penolong. Proses pembuatan gula kelapa ini memerlukan waktu selama 3 setengah jam di dapur produksi. Dari mulai menuangkan nira kelapa kedalam kuali besar sampai matang dan dilanjutkan dengan proses pencetakan gula kelapa.

Gula kelapa yang telah jadi harus segera di cetak sebelum mengeras. Cetakan gula kelapa yang digunakan terbuat dari bambu. Gula kelapa yang akan dicetak di tuangkan ke pencetakan bambu menggunakan gayung. Proses pencetakan ini dilakukan selama 10 menit. Berikutnya adalah proses pendinginan dimana proses ini, gula kelapa yang telah di letakkan di pencetakan bambu di angin-anginkan selama 10 menit, kemudian gula kelapa akan mengeras dengan cepat dan dapat langsung dilepaskan dari cetakan bambu tersebut.

Berikutnya, gula kelapa yang telah mengeras akan di letakkan di dalam box kayu. Box kayu tersebut terlebih dahulu telah disediakan oleh pengumpul gula kelapa sehingga, pemilik usaha hanya perlu memasukkan gula kelapa tersebut kedalam box kayu. Rata-rata gula kelapa didalam box kayu tersebut memiliki berat sekitar $10 \mathrm{~kg}$. setetelah di masukkan kedalam box kayu maka petani akan menyerahkan gula kelapa tersebut kepada pengumpul. Pengumpul yang akan menjemput gula kelapa yang siap dijual.

\section{Analisis Cost Volume Profit}

Cost Volume Profit merupakan alat analisis mengenai hubungan biaya, laba dan volume penjualan. Analisis Cost Volume Profit ini dapat memperhitungkan perencanaan laba dengan keuntungan yang diinginkan berdasarkan biaya-biaya yang diketahui. 


\section{Biaya Produksi Usaha Home Industry Gula Kelapa}

Biaya produksi usaha Home Industry gula kelapa terdiri dari biaya tetap dan biaya variabel. Biaya tetap merupakan biaya yang tidak berubah dengan adanya perubahan tingkat volume produksi gula kelapa sebaliknya biaya variabel adalah biaya yang akan berubah dengan adanya perubahan tingkat volume produksi gula kelapa.

\section{BiayaVariabel}

Biaya variabel merupakan biaya yang jumlahnya akan berubah sesuai dengan tingkat volume produksi yang dihasilkan. Pada penelitian ini biaya variabel terdiri atas biaya bahan baku, biaya bahan penolong, biaya bahan bakar dan biaya tenaga kerja. Berikut ini adalah tabel biaya variabel produksi gula kelapa per produksi :

Tabel 3. Biaya Variabel Produksi Gula Kelapa

\begin{tabular}{cccr}
\hline No. & \multicolumn{1}{c}{ Uraian } & Biaya (Rp/Produksi) & $\%$ \\
\hline 1. & Biaya Bahan Penolong: & & \\
& Kapur Sirih & $3.500,00$ & 6,63 \\
& $\quad$ Kelapa Parut & $3.250,00$ & 6,16 \\
2. & Biaya Bahan Bakar & $4.333,00$ & 8,21 \\
3. & Plastik & $7.177,78$ & 13,60 \\
4. & Biaya Tenaga Kerja & $34.500,00$ & 65,39 \\
\hline & Biaya Variabel & $52.761,78$ & 100,00 \\
\hline
\end{tabular}

Sumber: Data Primer Diolah, 2018

Berdasarkan pada Tabel 3, biaya variabel untuk memproduksi gula kelapa sebesar Rp.52.761/produksi. Biaya ini merupakan jumlah dari keseluruhan biaya variabel dari 45 home industry. Kontribusi biaya variabel terbesar terdapat pada biaya tenaga kerja. Hal tersebut terlihat pada tabel biaya tenaga kerja sebesar Rp. 34.500/produksi. Jika dibandingkan dengan penelitian Mugiono dkk (2014), pada biaya tenaga kerja sebesar Rp. 5.468/produksi Perbedaan biaya ini dikarenakan setiap daerah memiliki harga dan upah yang berbeda-beda.

\section{BiayaTetap}

Biaya tetap adalah biaya yang tidak berubah walaupun tingkat volume produksinya berubah. Pada penelitian ini biaya tetap terdiri atas biaya penyusutan alat seperti kuali, pengaduk kayu, bambu, serumbung, sabit, sutil, parutan kelapa, jerigen kecil, jerigen besar, gayung, tungku dan penyusutan dapur produksi. Berikut ini adalah Tabel 4 biaya tetap produksi gula kelapa per produksi : 
Tabel 4. Biaya Tetap Produksi Gula Kelapa

\begin{tabular}{llrr}
\hline No & \multicolumn{1}{c}{ Uraian } & Biaya (Rp/Produksi) & $\%$ \\
\hline 1 & Biaya Penyusutan : & 744,33 & \\
& Kuali & 14,00 & 4,29 \\
& Pengaduk Kayu & 2,42 & 0,08 \\
& Bambu & 9,00 & 0,01 \\
& Serumbung & 81,82 & 0,05 \\
& Sabit & 3,07 & 0,47 \\
& Sutil & 3,33 & 0,02 \\
& Parutan Kelapa & 411,89 & 0,02 \\
& Jerigen Kecil & 14,96 & 2,37 \\
& Jerigen Besar & 17,96 & 0,09 \\
& Gayung & 52,11 & 0,10 \\
& Tungku & $1.374,60$ & 0,30 \\
& Dapur Produksi & $14.637,04$ & 7,92 \\
& Sewa Batang & $17.366,53$ & 84,28 \\
\hline \multicolumn{2}{c}{ Biaya Tetap } & & 100,00 \\
\hline
\end{tabular}

Sumber: Data Primer Diolah, 2018

Biaya tetap selama satu kali produksi gula kelapa sebesar Rp. 17.366,53.729,49 (Tabel 4). Biaya ini merupakan jumlah dari keseluruhan biaya tetap dari 45 home industry. Kontribusi biaya tetap yang paling besar berasal dari biaya sewa batang sebesar $84,28 \%$ dan dapur produksi sebesar 7,92\%.. Besarnya kontribusi biaya dapur produksi ini dikarenakan harga awal pembuatan dapur produksi yang besar. Rata-rata pembuatan dapur produksi sebesar Rp. 9.896.666,67.

Peralatan yang paling mahal terletak pada kuali besar yang harganya sangat mahal. Harga satuan kuali besar termurah yaitu Rp. 100.000 yang terbuat dari alumunium dan kuali termahal yaitu Rp. 5.000.000 yang terbuat dari besi. Beberapa pemilik usaha mengatakan bahwa tidak dapat membeli kuali besar yang terbuat dari besi karena sangat mahal sehingga mereka hanya mampu membeli kuali besar yang terbuat dari alumunium saja.

\section{Produksi dan Penerimaan}

Penerimaan usaha home industry gula kelapa di Dusun Hibrida Desa Pal 30 Kecamatan Lais Kabupaten Bengkulu Utara ini berbentuk hasil penjualan produksi yang dihasilkan. Jumlah produksi gula kelapa di Dusun Hibrida ini relatif rendah, menurut petani pada waktu penelitian nira kelapa yang didapat petani untuk bahan baku pembuatan gula kelapa sedang mengalami penyusutan sehingga jumlah produksi juga mengalami penurunan. Hal ini dikarenakan musim yang tidak menentu sehingga mempengaruhi nira yang dihasilkan. 
Penerimaan juga dipengaruhi oleh harga. Harga pada pemilik usaha gula kelapa sudah ditentukan oleh pedagang pengumpul. Rata-rata harga gula kelapa yang diberikan oleh pedagang pengumpul kepada pemilik usaha gula kelapa adalah Rp. 8.700/Kg. sehingga dengan jumlah produksi yang sebesar $15,16 \mathrm{Kg} /$ Produksi penerimaan yang diterima oleh pemilik usaha sebesar Rp. 130.311 selama sekali produksi.

Pada penelitian Badrudin R. dkk (2004) jumlah produksi yang dihasilkan oleh pemilik usaha sebesar $35 \mathrm{Kg}$ dengan harga jual sebesar Rp. 2.147,5 sehingga penerimaan yang didapatkan oleh pemilik usaha sebesar Rp. 75.226. Hal ini menunjukkan bahwa penerimaan yang didapatkan oleh pemilik usaha gula kelapa pada tahun 2018 sudah meningkat dibandikan pada tahun 2004. Jumlah produksi mengalami penurunan pada tahun 2018 tetapi harga yang ditetapkan oleh pengumpul sudah lebih tinggi dibandingkan pada tahun 2004 sehingga penerimaan pemilik usaha juga mengalami peningkatan. Hal ini dipicu oleh keadaan perekonomian pada saat ini yang sudah serba mahal sehingga pedagang pengumpul juga harus meningkatkan harga jual pada pemilik usaha sehingga kedua belah pihak tidak ada yang mengalami kerugian.

\section{Laporan Rugi/Laba}

Pendapatan merupakan hasil selisih antara penerimaan dikurangi dengan biaya. Pendapatan dapat dilihat dengan menggunakan laporan rugi/laba. Dengan laporan rugi/laba kita dapat mengetahui laba bersih dari penjualan gula kelapa. Berikut adalah laporan rugi/laba usaha Home Industry Gula Kelapa di Dusun Hibrida Desa Pal 30 Kecamatan Lais Bengkulu Utara.

Contribution Margin merupakan selisih antara hasil penjualan dikurangi biaya variabel. Hal ini dapat diartikan sebagai jumlah yang tersedia untuk menutupi biaya tetap dan setelah dikurangi dengan biaya tetap maka akan menjadi laba untuk periode tertentu.Contribution Margin Ratio berfungsi sebagai penetapan suatu kebijakan dalam usaha. Apabila Contribution Margin Ratio besar maka dapat diprediksi bahwa adanya kenaikan laba dari suatu kenaikan volume penjualan. Sebaliknya apabila Contribution Margin Ratio kecil, maka pemilik usaha harus mengambil keputusan yaitu mengurangi biaya-biaya dan beban usaha lainnya. 
Tabel 5. Laporan Rugi/Laba Produksi Gula Kelapa

\begin{tabular}{clc}
\hline No. & \multicolumn{1}{c}{ Uraian } & Jumlah (Rp/Produksi) \\
\hline 1. & Penjualan & $130.311,00$ \\
2. & Biaya Variabel & $52.761,00$ \\
3. & Contribution Margin & $77.550,00$ \\
4. & Biaya Tetap & $17.366,53$ \\
5 & Laba & $60.183,47$ \\
\hline
\end{tabular}

Sumber: Data Primer Diolah, 2018

Berdasarkan Tabel 6, laba yang dihasilkan dari produksi Home Industry Gula Kelapa di Dusun Hibrida Kecamatan Lais Kabupaten Bengkulu Utara sebesar Rp. 60.183,47. Hal ini berarti pemilik usaha mendapatkan keuntungan sebesar Rp.60.183,47 per produksi (sehari). Dengan demikian, pemilik usaha gula kelapa di dusun ini pemperoleh pendapatan bersih rata-rata Rp. 1. 805. 504,10 .

Contribution Margin menunjukkan kemampuan usaha Home Industry Gula Kelapa di Dusun Hibrida Desa Pal 30 Kecamatan Lais Kabupaten Bengkulu Utara untuk menutupi biaya variabel maupun biaya tetap untuk memperoleh laba. Dari Tabel 6 di atas dapat dilihat bahwa Contribution Margin yang didapat dari usaha gula kelapa ini lebih besar dari biaya tetap yang dikeluarkan sehingga usaha gula kelapa ini mampu memperoleh keuntungan dari penjualan. Jika jumlah margin kontribusi lebih besar dari biaya tetap maka perusahaan akan memperoleh laba dan sebaliknya perusahaan akan memperoleh kerugian jika margin kontribusi lebih kecil dari biaya tetap atau perusahaan akan mengalami impas jika margin kontribusi sama dengan biaya tetap (Assa, 2013).Contribution Margin Ratio sebesar 59,51\%, hal ini menunjukkan bahwa setiap satu rupiah kenaikan penjualan, total Contribution Margin akan meningkat sebesar Rp. 0.59. Contribution Margin Ratio sangat berguna untuk menetapkan kebijakan dalam berbisnis.

\section{Break Event Point}

Break Event Point merupakan analisis untuk mengetahui berapa volume penjualan minimum agar usaha tidak mengalami kerugian tetapi juga tidak memperoleh laba. Break Event Point ini membantu pemilik usaha untuk meningkatkan penjualan mereka di atas nilai Break Event Point dan berusaha untuk menjauhi nilai dibawah Break Event Point. Tabel 6 menginformaiskan perhitungan Break Event Point produksi gula kelapa. 
Tabel 6. Break Event Point Produksi Gula Kelapa

\begin{tabular}{clr}
\hline No. & Uraian & \multicolumn{1}{c}{ Jumlah } \\
\hline 1. & Total Penjualan (TR) (Rp/Produksi) & 130.311 \\
2. & Total Biaya (TC) (Rp/Produksi) & $70.127,53$ \\
3. & Biaya Variabel (Rp/Produksi) & $52.761,00$ \\
4. & Biaya Tetap (Rp/Produksi) & $17.366,53$ \\
5. & Contribution Margin (Unit) & $5.219,72$ \\
6. & Contribution Margin (Rasio)(\%) & 59,51 \\
7. & Break Event Point (Unit) & 3,33 \\
8. & Break Event Point (Penjualan) & $29.182,54$ \\
\hline
\end{tabular}

Sumber: Data Primer Diolah, 2018

Pada Tabel 6, dapat disimpulkan bahwa tabel diatas merupakan jumlah rupiah yang harus dicapai pemilik usaha dalam satu kali produk agar tidak mengalami kerugian dan juga tidak mengalami keuntungan. Dalam satu kali produksi pemilik usaha harus memproduksi gula kelapa dengan nilai Rp. 29.182,54. Apabila nilai titik impas tersebut diperoleh maka usaha tersebut tidak rugi juga tidak untung. Lalu, apabila usaha gula kelapa tersebut memperoleh nilai di atas titik impas rupiah tersebut maka usaha gula kelapa akan dikatakan untung. Sebaliknya, apabila usaha gula kelapa memperoleh nilai dibawah titik impas rupiah maka usaha akan mengalami kerugian.

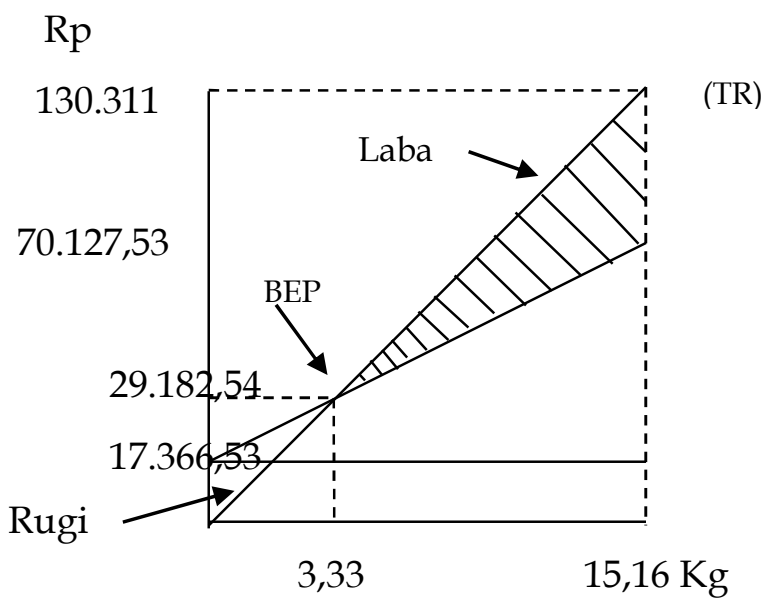

Gambar 4.

Grafik Break Event Point 
Nilai titik impas per unit Usaha Gula Kelapa (lihat Gambar 1 grafik) menunjukkan bahwa jumlah seluruh gula kelapa yang harus diproduksi dalam satu hari sebesar $3,33 \mathrm{Kg}$. Hal ini menunjukkan apabila pemilik usaha memproduksi gula kelapa kurang dari 3,33 Kg maka usaha tersebut akan mengalami kerugian. Sebaliknya apabila usaha gula kelapa dapat memproduksi gula kelapa melebihi 4,91 Kg maka usaha tersebut akan mengalami keuntungan. Pada penelitian Sukiman, dkk (2007), posisi Break Event Point (BEP) adalah suatu keadaan pada saat nilai penjualan hasil produk pada suatu periode tertentu besarnya sama dengan biaya yang dikeluarkan. Pada penelitian ini BEP harga prmilik usaha sebesar Rp. 1.122,31 dan BEP per unit sebesar 43,87 Kg. Dengan mengetahui posisi BEP, pemilik usaha dapat memperhitungkan dan merencanakan profit margin yang dapat dicapai atau diharapkan dan upaya pengembangan usaha tersebut.

\section{Profitabilitas dan Sensitivitas}

Profitabilitas merupakan perhitungan untuk mengetahui kemampuan usaha Home Industry Gula Kelapa untuk memperoleh laba. Profitabilitas diperoleh dari perkalian antara Margin Of Safety (MOS) dan Marginal Income Ration (MIR). Margin Of Safety (MOS) merupakan titk aman usaha sehingga didapatkan seberapa jauh penjualan gula kelapa boleh turun dari rencana penjualan impas. Marginal Income Ratio merupakan alat analisis yang digunakan untuk melihat persentase hasil penjualan dapat menutupi biaya tetap sehingga memperoleh laba.

Analisis Degree of Operating Leverage (DOL) merupakan alat analisis untuk menunjukkan sejauh mana laba usaha Home Industry Gula Kelapa di Dusun Hibrida Desa Pal 30 Kecamatan Lais Kabupaten Bengkulu Utara dapat berubah apabila terjadi penurunan atau peningkatan jumlah penjualan gula kelapa.

Tabel 7. Profitabilitas dan Sensitivitas Produksi Gula Kelapa

\begin{tabular}{clr}
\hline No. & \multicolumn{1}{c}{ Uraian } & \multicolumn{1}{c}{ Jumlah } \\
\hline 1. & Penjualan (Rp/Produksi) & $130.311,00$ \\
2. & Biaya Variabel (Rp) & $52.761,00$ \\
3. & Laba Bersih (Rp) & $60.183,47$ \\
4. & Contribution Margin (Rp) & $77.550,00$ \\
5. & Break Event Point (Rp) & $29.182,54$ \\
6. & Margin of Safety (MOS) (\%) & 77,60 \\
7. & Marginal Income Ratio (MIR) (\%) & 59,51 \\
8. & Profitabilitas (\%) & 46,00 \\
9. & Degree of Operating Leverage (DOL) (\%) & 1,29 \\
\hline
\end{tabular}

262 | Efa Yulita Fitri; Nusril; Reswita; Profitabilitas dan Evaluasi Kinerja ... 
Dari Tabel 8, Margin Of Safety gula kelapa di Dusun Hibrida Desa Pal 30 Kecamatan Lais Kabupaten Bengkulu Utara sebesar 77,60\% sedangkan Marginal Income Ratio sebesar 59,51\%. Marginal Income Ratio menunjukkan bahwa pendapatan usaha Home Industry Gula Kelapa yang tersedia untuk menutupi biaya tetap dan memperoleh laba. Profitabilitas atau kemampuan usaha Home Industry Gula Kelapa untuk menghasilkan laba sebesar 46\%. Hal tersebut menunjukkan bahwa usaha Home Industry Gula Kelapa di Dusun Hibrida Kecamatan Lais Kabupaten Bengkulu Utara ini mampu menjual produk gula kelapa sesuai dengan yang dianggarkan dengan laba yang diperoleh sebesar 46\%. Menurut Martusa dan Diva (2010), semakin besar nilai Margin of Safety Ratio usaha agroindustri gula kelapa, maka semakin kecil resikonya untuk mengalami kerugian.

Degree Of Operating Leverage gula kelapa sebesar 1.29. Hal ini menunjukkan bahwa apabila terjadi penurunan atau peningkatan penjualan gula kelapa sebesar 1\% maka laba akan berubah sebesar 1.29\%. Setiap kenaikan penjualan $1 \%$ maka laba pun akan meningkat sebesar nilai sensitivitas tersebut. Apabila nilai Degree Of Operating Leverage kecil laba usaha tidak sensitif terhadap perubahan penjualan yang terjadi. Peningkatan penjualan tidak akan berdampak besar pada peningkatan laba usaha, begitupun dengan penurunan penjualan tidak akan membuat laba usaha mengalami kerugian besar dan masih bisa mendapatkan laba (Martusa dan Diva, 2010).

\section{Importance Performance Analysis (IPA)}

Importance Performance Analysis (IPA) merupakan alat analisis untuk mengetahui tingkat penerimaan konsumen pada produk gula kelapa. Importance Performance Analysis (IPA) dilakukan dengan cara penskoran/ penilaian terhadap masing-masing atribut yang digunakan melalui kuesioner. Konsumen tentunya memiliki harapan terhadap kualitas produk yang diberikan pemilik usaha untuk memenuhi keinginan konsumen. Terpenuhnya keinginan konsumen terhadap produk akan menimbulkan kepuasan tersendiri oleh konsumen sehingga konsumen tidak merasa rugi untuk membeli gula kelapa.

Berdasarkan nilai rata-rata tingkat kinerja lebih besar dari nilai rata-rata tingkat kepentingan $(3,87>3,79)$. Oleh karena itu secara rata-rata harapan dan kepuasan konsumen untuk berbagai atribut produk sudah terpenuhi. Namun, terpenuhinya harapan ini belum begitu maksimal karena selisih antar nilai tingkat kinerja dan nilai tingkat kepentingan yang kecil sebesar 0.08 . Hal ini berarti, pemilik usaha harus memperhatikan berbagai atribut-atribut yang dinilai kinerjanya masih kurang.

Diagram Kartesius dapat menggambarkan titik potong dari rata-rata atribut-atribut tingkat kepentingan dan tingkat kinerja. Setiap kuadran yang ada pada diagram Kartesius dibagi dari garis tengah yang diperoleh dari nilai total 
rata-rata tingkat kinerja dan tingkat kepentingan $(3.87$; 3.79).Berikut adalah hubungan antara hasil pengukuran tingkat kinerja dan tingkat kepentingan pada diagram Kartesius :

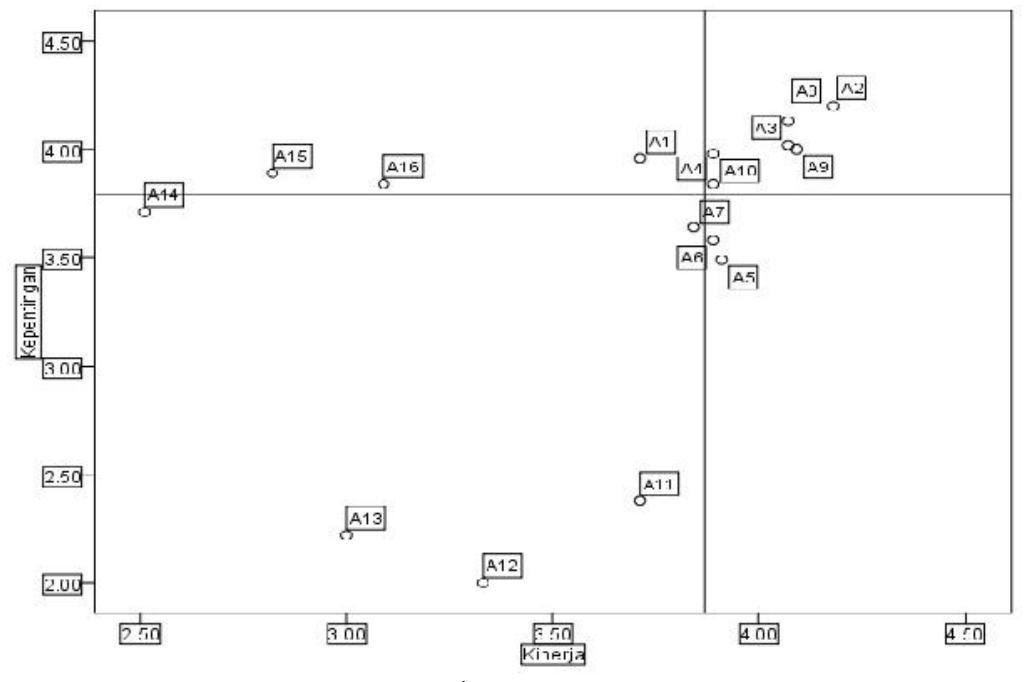

Gambar 2.

Diagram Kartesius Produk Gula Kelapa

\section{Kuadran 1 Prioritas Utama}

Pada Diagram Kartesius Kuadran I terdiri dari 2 atribut yamg menjadi prioritas utama dalam produk gula kelapa. Berikut adalah atribut-atribut yang terdapat pada kuadran I:

Tabel 8. Atribut-atribut Produk Gula Kelapa Pada Kuadran I Diagram Kartesius

\begin{tabular}{ccl}
\hline No & Kode Atribut & \multicolumn{1}{c}{ Keterangan } \\
\hline 1 & A1 & Harga beli gula kelapa \\
2 & A15 & Papan nama tempat pengolahan gula kelapa \\
3 & A16 & Promosi dari mulut ke mulut (word of mouth) \\
\hline
\end{tabular}

Sumber: Data Primer Diolah, 2018

Pada kuadran I, atribut-atribut tersebut menunjukkan bahwa konsumen menganggap harga beli gula kelapa, papan nama tempat pengolahan gula kelapa dan promosi dari mulu ke mulut (word of mouth) mempengaruhi tingkat penerimaan konsumen. Namun atribut-atribut tersebut kinerjanya belum sesuai dengan yang diharapkan oleh konsumen. Oleh karena itu, pemilik usaha perlu meningkatkan kinerja produk gula kelapa yang terdapat pada kuadran ini karena keberadaan atribut-atribut ini dianggap penting oleh konsumen gula 
kelapa. Pada penelitian Budiman Y. dkk (2013), atribut pada kuadran I menunjukkan tingkat kepentingan pada atribut tinggi tetapi mempunyai tingkat pelaksanaan kinerja yang dinilai rendah atau pada kenyataannya atribut-atribut pada kuadran I belum sesuai seperti yang diharapkan (tingkat kepuasan yang diperoleh masih sangat rendah) sehingga konsumen mengharapkan adanya perbaikan terhadap atribut-atribut tersebut.

\section{Kuadran II. Pertahankan Prestasi}

Tabel 9. Atribut-atribut Produk Gula Kelapa Pada Kuadran II Diagram Kartesius

\begin{tabular}{ccl}
\hline No & Kode Atribut & \multicolumn{1}{c}{ Keterangan } \\
\hline 1 & A2 & Kehigienisan gula kelapa \\
2 & A3 & Rasa gula kelapa dan makanan/minuman \\
3 & A4 & Warna gula kelapa \\
4 & A8 & Daya tahan gula kelapa \\
5 & A9 & Kemudahan mendapatkan gula kelapa \\
6 & A10 & Kelarutan gula kelapa \\
\hline
\end{tabular}

Sumber: Data Promer Diolah, 2018

Atribut-atribut yang menempati kuadran II menunjukkan dianggap penting oleh konsumen yang telah berhasil dicapai dan sangat memuaskan. Oleh sebab itu, atribut-atribut tersebut harus dipertahankan dan harus terus dikelola dengan baik. Atribut-atribut di kuadran II ini memiliki daya tarik yang baik sehingga konsumen dapat menerima gula kelapa dan membelinya.

Atribut-atribut pada kuadran II terdapat pada kategori pertahankan prestasi memiliki tingkat kepentingan yang tinggi dan kinerjanya juga dinilai baik oleh konsumen. Kuadran ini memperliharkan atribut-atribut produk gula kelapa perlu dipertahankan dan terus ditingkatkan.

\section{Kuadran III. Prioritas Rendah}

Pada kuadran III ini, atribut-atribut tersebut menunjukkan bahwa menjadi prioritas rendah pada produk gula kelapa. Atribut-atribut yang berada pada kuadran III ini menunjukkan bahwa atribut tersebut kurang penting pengaruhnya bagi konsumen. Atribut-atrbut tersebut dianggap biasa saja dan kurang penting. Oleh karena itu, pemilik usaha tidak perlu memprioritaskan atau terlalu memberikan perhatian kepada atribut-atribut tersebut. 
Tabel 10. Atribut-atribut Produk Gula Kelapa Pada Kuadran III Diagram Kartesius

\begin{tabular}{ccl}
\hline No & Kode Atribut & \multicolumn{1}{c}{ Keterangan } \\
\hline 1 & A7 & Tekstur gula kelapa \\
2 & A11 & Kemasan yang Menarik \\
3 & A12 & Label Komposisi Bahan \\
4 & A13 & Label Halal \\
\hline
\end{tabular}

Sumber: Data Primer Diolah, 2018

Pada atribut-atribut di kuadran III ini dianggap kurang penting dan kurang begitu berpengaruh kepuasannya oleh konsumen, tetapi dalam pelaksanaannya atribut-atribut ini juga memerlukan perhatian, karena jika tidak maka kinerjanya akan turun dan dapat mempengaruhi keseluruhan produk gula kelapa.

\section{Kuadran IV. Berlebihan}

Atribut-atribut pada kuadran IV merupakan atribut yang cenderung berlebihan. Atribut-atribut tersebut sebagai berikut:

Tabel 11. Atribut-atribut Produk Gula Kelapa Pada Kuadran IV Diagram Kartesius

\begin{tabular}{ccl}
\hline No & Kode Atribut & \multicolumn{1}{c}{ Keterangan } \\
\hline 1 & A5 & Ukuran gula kelapa \\
2 & A6 & Bentuk gula kelapa \\
\hline
\end{tabular}

Sumber: Data Primer Diolah, 2018

Atribut-atribut yang berada pada kuadran IV ini menunjukkan bahwa atribut tersebut dianggap kurang bagi konsumen tetapi, kinerja dan pelaksanaannya terlalu berlebihan. Oleh karena itu, lebih baik sumber daya yang ada pada atribut-atribut tersebut dialokasikan kepada atribut-atribut lain yang memiliki prioritas atau penanganannya lebih tinggi sehingga dapat meningkatkan kinerja pada atribut-atribut tersebut.

Menurut Melfa Yola danBudianto (2013), kepuasan dapat dilihat dari beberapa idikator antara lain: Kepuasan terhadap kemampuan untuk melaksanakan jasa yang dijanjikan, kepuasan terhadap kemauan membantu konsumen, kepuasan terhadap pengetahuan dan kesopanan. 


\section{SIMPULAN DAN SARAN}

\section{Simpulan}

1. Keuntungan yang diperoleh dari penjualan produk gula kelapa sebesar Rp.60.183,47 per Produksi. Titik impas penjualan yang diperoleh sebesar Rp.29.182,54 dengan titik impas per unit sebesar 3,33 Kg per produksi. Profitabilitas produk gula kelapa untuk memperoleh laba sebesar $46 \%$ dan Degree of Operating Laverage gula kelapa sebesar 1.29\%.

2. Atribut yang menurut konsumen penting dan kinerjanya sudah baik adalah kehigienisan gula kelapa, rasa gula kelapa dalam olahan makanan/minuman, warna gula kelapa, daya tahan gula kelapa, kemudahan mendapatkan gula kelapa dan kelarutan gula kelapa, atributatribut tersebut perlu dipertahankan. Kemudian atribut yang dianggap penting namun kinerjanya belum sesuai yaitu, harga beli gula kelapa, papan nama tempat pengolahan gula kelapa dan promosi, atribut-atribut tersebut perlu diprioritaskan perbaikannya.

\section{Saran}

1. Usaha Home Industry gula kelapa di Dusun Lais Hibrida Pal 30 Kecamatan Lais Kabupaten Bengkulu Utara ini sudah menguntungkan. Dengan demikian usaha ini dapat dikembangkan lagi baik itu dalam produksi maupun pemasarannya.

2. Sebaiknya pihak pemilik usaha dapat mendirikan kelembagaan sendiri seperti koperasi. Adanya kelembagaan seperti halnya koperasi pada tingkat produsen/pemilik usaha, harga jual produk dapat ditingkatkan dan aspek pemasaran dapat dikendalikan oleh pemilik usaha. Dengan begitu harga tidak akan mudah untuk dikendalikan oleh toke dan dengan adanya kelembagaan dapat memudahkan pemerintah untuk memberikan bantuan.

\section{DAFTAR PUSTAKA}

Badrudin R., Satria P. U., \& Lenny M. 2004. Pendapatan, Efisiensi Usaha Gula Kelapa Dan Pemasaranya Di Desa Pal30 Kabupaten Bengkulu Utara. Jurnal Agrisep. 2 (2). 135-144

Budiman Y., Sukiyono K., \& Sumantri B. 2013. Kajian Agribisnis Usaha Gula Aren Di Kabupaten Rejang Lebong. Jurnal Agrisep. Volume 12 (1):51-68

Hanum, Z 2001 Pengaruh Profitabilitas Teradap Modal Kerja Pada Perusahaan Makanan Dan Minimum Yang Terdaftar Di Bursa Efek Indonesia. Jurnal Manajemen E Bisnis. 11 (2):1-15.

Dinas Perindustrian dan Perdagangan. 2017. IKM Gula Merah: Bengkulu.

Martusa, D. 2010. Penerapan Cost Volume Profit Analysis Sebagai Alat Bantu Dalam Perencanaan Penjualan Atas Target Laba Yang Ditetapkan 
(Studi Kasus Pada Toko Mei Pastry). Akurat Jurnal Ilmiah Akuntansi. 1(3):1-19.

Mugiono, Marwanti, S., Awami, S. N. 2014. Analisis Pendapatan Usaha Gula Merah Kelapa (Studi Kasus Di Desa Medono Kecamatan Kaliwiro Kabupaten Wonosobo). MEDIAGRO. 10 (2):22-31.

Mulyadi. 2001. Akuntansi Manajemen, Edisi 3. Jakarta (ID): Salemba Empat.

Reswita. 2010. Panduan Praktikum Akuntansi Manajamen. Jurusan Sosial Ekonomi Pertanian Universitas Bengkulu

Simamora, H. 2012. Akuntansi Manajemen, Edisi Ketiga. Star Gate Publisher: Riau. Sukiman, S., Dumasari, D., \& Budiningsih, S. 2007. Analisis Kelayakan Usaha Agroindustri Gula Kelapa Di Desa Panerusan Kulon Kecamatan Susukan Kabupaten Banjarnegara. Agritech. 9 (1):21-32.

Verawati, E. 2014. Penerapan Metode CVP (Cost-Volume-Profit) Sebagai Alat Bantu Analisis Perencanaan Laba Dalam Mencapai Target Perusahaan PAda UKM Vinito Brownis. Skripsi Fakultas Ekonomi dan Bisnis.

Yola, M., \& Budianto, D. 2016. Analisis kepuasan konsumen terhadap kualitas pelayanan dan harga produk pada supermarket dengan menggunakan metode Importance Performance Analysis (IPA).Jurnal Optimasi Sistem Industri, 12 (12):301-309. 